\title{
Political participation of women in Central and Eastern Europe: comparative analysis
}

UDC 329-055.2(4-11/19)

DOI https://doi.org/ 10.24195/2414-9616-

2019-4-62-68

Surnina-Dalekorei Olha Anatoliivna

$\mathrm{PhD}$ in Political Sciences,

Associate Professor of the Department of

Political Sciences and Public Administration of Uzhhorod National University

Universitetska str., 14, Uzhhorod, Ukraine

\begin{abstract}
The paper describes the process of transformation of political participation of women under the influence of various factors in the form of the comparative analysis. The aim of the study is to identify and systematize the factors influencing the level of political participation of women in developing economies. The relevance of the topic is determined by the necessity to include women as active participants in the political process of the countries of developing economies, and the creation of mechanisms that promote the growth of the role of women in authorities as a valid condition of representative democracy. The research methodology is based on the theoretical approaches to the analysis of political representation and women's participation in authorities, and also on the concept according to which the state of political participation of women is determined by a complex of socio-economic, cultural and political factors. The western researchers find that socioeconomic factors (women's employment, women's educational level, the level of the state economic development, the strength of women's movement), cultural factors (dominant religion, ratification of CEDAW, abortion rights) and the political factors (electoral system, left party government, degree of democracy) play a role in the accounting for the variation in the degree of gender inequality in the political representation around the world. The empirical basis of work is made by the wide circle of statistical materials. While working with it the author used the elements of the statistical analysis, and computer methods of data processing (in a standard package SPSS). Statistical analysis of the trends of women's political participation in Slovakia, Poland, Ukraine and Russia has shown that the level of socialeconomic development, the relevant cultural environment and institutional factors are important mechanisms, determining the level of political participation of women in transition countries.

Key words: Central and Eastern Europe, Slovakia, Poland, Ukraine, Russia, women's political participation
\end{abstract}

Introduction. The desire of the CEE countries to build a Western model of liberal democracy at the turn of the 20-21st centuries has raised the necessity of ensuring the political rights of citizens. One of the problems of democracy transition was the need to form a new type of political culture, with the corresponding change of the forms of political participation of ordinary citizens according to the principle of equality. This principle underlies the normative theories of democracy, providing that women on the equal basis with the men should share their participation in the process of state governance. Most countries with well-established and developed democratic institutions have approached this norm, in contrast to the CEE countries. This might be evidenced by the fact that, with the beginning of transitional processes, the share of women in the national parliaments of the countries of the region has decreased to $10 \%$ (on the average for CEE), and in some regions even to $5 \%$.

Studies on the women representation in politics have been intensively developing in the West since the 1970s. As a rule, general literature, touching upon women and politics includes three main clusters of variables explaining national variations of women representation at the level of authority: political, socio-economic, and cultural (R. Inglehart, P. Norris, K. Welzel (2002) [14], R. Matland $(2003,2004,2005)$ [21; 20; 19], L. Kenworthy and M. Malami (1999) [17], J. Viterna, K.M. Fallon, J. Beckfield (2008) [36], S. Lindberg (2004) [18], P. Norris, R. Inglehart (2000) [26], M. Jones (2007) [15], etc.).

Most current researches focus on 25-30 developed democratic countries and demonstrate that institutional factors have the most explanatory power. Researches of less developed countries, on the contrary, emphasize the role of socio-economic and cultural barriers that impede women's representation, for example: women's low level of education and labor market participation, poverty and non-egalitarian social values that can be reinforced by the Catholic, Muslim and Orthodox religions.

The relevance of the topic is determined by the necessity to include women as active participants in the political process of the countries of developing economies, and the creation of mechanisms that promote the growth of the role of women in authorities as a valid condition of representative democracy.

Comparative analysis, in the author's opinion, is the most expedient method to study cases which, on the one hand, have a certain common background, and on the other, are characterized by a number of distinctive features caused by different post-socialist transformations' conditions. Comparative "international" research, according to the author, provides a deeper understanding of the connections between the formal complete volume of rights to the citizens granting, caused by the liberal-democratic practice, and the actual provision of these rights to the members of societies, rather than the analysis within a national context.

The scientific novelty of the study is to conduct a comparative analysis of the political participation of women in the context of transformation as a result of the influence of socio-economic, national-cultural and institutional factors. Thus, for the first time, women's participation in political processes in the CEE region is explained not only through the prism of traditional 
factors - cultural and socio-economic - but also as a result of the influence of the institutional environment of the post-socialist countries in the context of political transformation.

Our study takes full account of the socio-economic and cultural aspects of women's representation, as well as the role of political institutions - electoral systems and political parties as factors of women's political representation in the CEE countries in the 1990s of XXthe beginning of the XXI century.

The work is based on extensive statistical material used by the author in the traditional and processed form. The main sources of statistical information are the data of the sites of the State Statistics Service of the Russian Federation [7], Ukraine [28], Slovakia [29] and Poland [31], the data of the official websites of the Central Election Commission of Russian Federation [4], Ukraine [5] and Poland [27], as well as the data of the official Government websites of Slovakia, Poland, Russia and Ukraine (1991-2007) [11; 16; 33; 12], data of the Inter-Parliamentary Union (1989-2007) [13] and Freedom House (1989-2007) [8]. Important sources are also materials of the activities and history of women's organizations in Slovakia, Poland, Russia and Ukraine $[1 ; 2 ; 10 ; 34]$, as well as databases of leading women's organizations [3; 9], statistical compilations and reference books in original and electronic versions [6; 10;32; 35], official data of the Ministry of Justice of the Russian Federation and Ukraine [22; 23], National Court Register in Poland [25], Ministry of Interior of the Slovak Republic [24] as sources of information about civil society organizations existing in these countries.

Objective and Hypotheses. The objective of the study is to identify and systematize the factors influencing the level of political participation of women in developing economies.

The hypotheses of our research are:

1) the level of political participation of women positively correlates with their socio-economic status (the level of employment, education), and also depends on the level of economic development of the country and the strength of the women's movement as a whole;

2) cultural variables (the type of dominant religion, the legalization of abortion and the ratification of CEDAW) directly affect the proportion of women in national parliaments;

3) the proportional electoral system, the representation in the parliament of the parties of the left spectrum and the high rating of democratic freedoms of the country are the important determinants of the female parliamentarism indicators.

Methodology and data. The analysis is based on the method of identifying working variables, which is widespread in the Western political science, and namely in the works of L. Kenworthy, M. Malami (1999) [17], J. Viterna, K. Fallon, J. Beckfield (2008) [36]. The study of L. Kenworthy and M. Malami is an extencive sample of information (based on the sources of 146 countries), where national parliaments operate and statistical data are available (1999).

The dependent variable in our case is the percentage of seats in the national parliament obtained by women as a result of elections. In the countries with a bicameral parliament (Poland, Russia), only the lower house data is used. The original source is the data of IPU [13] and the official web-sites of the Central election commission of Poland, Ukraine, Russian (1991-2004) [27; 4; 5]. As well as data of the Statistical office of the Slovak Republic [30].

Independent variables are grouped into political factors (electoral system, left party government, degree of democracy), socio-economic factors (women's employment, women's educational level, the level of the state economic development, the strength of women's movement) and cultural factors (dominant religion, ratification of CEDAW, abortion rights).

We shall start with considering the whole set of operative variables. Socio-economic factors: the level of women education is measured by the number of women with complete secondary education of the total mass of students. The level of women employment is measured by the amount of women in general quantity of employed in the economy within the period from 1994 to 2002. The economic development is represented by the share of GDP per capita in dollars in the countries under analysis.

As the sources of data the official websites of state statistics of Slovakia, Poland, Russian and Ukraine (1994, 1998 and 2002) [29; 31; 7; 28] have been used. The strength of the women's movement has been defined by the number of national women's organizations, recognizing their task to increase the women political participation (1994-2002). As the data sources the statistical collection and reference books in original and electronic versions have been used [6; 10; 32; 35].

Cultural factors. As is generally known, culture belongs to the phenomenon that is difficult to define. Therefore, a number of variables to identify relationships have been used in the work. First, we have included a number of dummy variables representing the dominant religious tradition in each individual country. Thus, the prevailing religious tradition was measured using three dummy variables, where the 1 corresponds to Catholicism, the 2 - to Orthodoxy, and the 3 - to the Islam. We expect that each of these variables will be inversely related to the number of women's seats in parliament.

Secondly, the variable "ratification of CEDAW" is represented by the year of validity of this document (in the intervals 1994, 1998, 2002) since the date of signing of the Convention by each country. The inclusion of this variable is the evidence of governments obligations to modify their legislation in accordance with the principles of an international convention regarding gender equality. It is also expected that when the duration of this document increases, the government policy concerning women will become more qualitative rather than declarative.

The legalization of abortion is the third binary variable, where the 1 indicates that abortion is legal, and the 
0 indicates that abortion is prohibited. The liberalization of women's reproductive rights is an indicator of cultural orientations regarding women's roles and rights in a society. We expect a positive correlation between all the variables and the women representation.

Political factors. The electoral system is represented as an ordinal variable, where the majoritarian electoral system is assigned the value -0 , mixed 1 , and proportional -2 . The presence of left parties corresponds to the number of seats in the parliament (in percentage terms) occupied by the representatives of the left spectrum parties. The data sources are the IPU [13] and the official websites of the CEC of the Slovakia, Poland, Russian and Ukraine (1994-2002) $[30 ; 27 ; 4 ; 5]$. The level of democracy is measured using an ordinal scale developed by the International organization "Freedom House" [8]. Its scale ranges from 1 to 7 , where the highest marks mean greater level of political freedom. Official data presented on the website of the organization are the original source of information.

The values of all variables used in the analysis are presented in the data matrix for each country (Table 1).

To identify the correlation between the variables, the methods of multidimensional statistics (descriptive and factor analyses) have been used. On the basis of construction of the table of frequencies (data of four countries within the interval from 1994, 1998 and 2002), we have formed a table of the correlation dependence between the main variables and determined the correlation coefficient of Pearson.
Results. According to the analysis of data presented in the general matrix of significant variables of women's parliamentarism (Table 2), from three socio-economic variables that were considered, only the indicator of a country's economic development is consistently related to the proportion of women's seats in the parliament.

Despite the expectations, such a variable as "women's employment" demonstrated a negative connection with women's political representation, while the theoretical construction does not provide such a result. Such a variable as "women's educational attainment" did not show a correlation with the dependent variable at all (Table 3).

The coefficient of correlation of the variable - "strength of the women's movement" although demonstrating the expected positive connection, is far from being statistically significant. The results obtained substantially differ in several aspects from those already made conclusions regarding the effect of socio-economic factors. Contrary to such authors as J. Viterna, J. Beckfield, K. Fallon (2008) [36] we do not find evidence that the variable "women's educational attainment" affects the percentage of women's political representation. The results obtained also contradict to the findings of these authors in that the number of women in the labor force correlates positively with the percentage of women-parliamentarians.

The confirmation of the results obtained we find in the work of L. Kenworthy and M. Malami (1999) [17], who also do not reveal the positive effect of the interaction of these factors with the indicator of the women political representation on a global scale. The variable of "level of economic development of the country" turned out to

Table 1

Data table for each country

\begin{tabular}{|c|c|c|c|c|c|c|c|c|c|c|c|c|}
\hline Country & $\begin{array}{l}\frac{\pi}{\frac{\pi}{5}} \\
\frac{\partial}{n}\end{array}$ & $\begin{array}{l}\frac{\pi}{\frac{\pi}{5}} \\
\frac{\partial}{\omega}\end{array}$ & $\begin{array}{l}\frac{\pi}{\frac{\pi}{5}} \\
\frac{\partial}{\omega}\end{array}$ & $\begin{array}{l}\frac{\overline{0}}{\frac{\pi}{0}} \\
\frac{\pi}{0} \\
\frac{0}{0}\end{array}$ & $\begin{array}{l}\frac{0}{0} \\
\frac{\pi}{0} \\
\square\end{array}$ & $\begin{array}{l}\frac{\overline{0}}{0} \\
\frac{\pi}{0} \\
\frac{0}{0}\end{array}$ & $\begin{array}{l}\frac{\pi}{\tilde{D}} \\
\frac{\hat{n}}{\vec{x}} \\
\underline{\alpha}\end{array}$ & 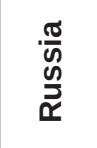 & $\begin{array}{l}\frac{\pi}{n} \\
\frac{\hat{n}}{\vec{x}} \\
\vec{\alpha}\end{array}$ & 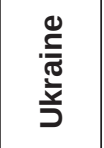 & 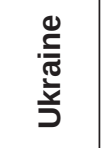 & 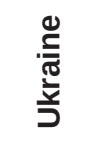 \\
\hline Year & 1994 & 1998 & 2004 & 1994 & 1998 & 2004 & 1994 & 1998 & 2004 & 1994 & 1998 & 2004 \\
\hline Women's employment & 46 & 0,44 & 0,45 & 0,45 & 0,44 & 0,46 & 0,48 & 0,48 & 49 & 0,49 & 0,51 & 0,49 \\
\hline $\begin{array}{r}\text { Women's ed } \\
\text { attainm }\end{array}$ & 0,4 & 0,43 & 0,49 & 0,48 & 0,49 & 0,48 & 0,49 & 0,5 & 0,58 & & 0,49 & 0,46 \\
\hline Level of GDP & 2,571 & 3,793 & 7,806 & 2,399 & 3,887 & 6,617 & 1,868 & 1,867 & 4,113 & 0,728 & 0,846 & 1,366 \\
\hline $\begin{array}{l}\text { Women' } \\
\text { parliamer }\end{array}$ & 14,66 & 13,33 & 16,7 & 13,04 & 13,04 & 20,22 & 14,53 & 7,56 & 10,07 & 4,5 & 7,92 & 5,33 \\
\hline $\begin{array}{r}\text { Strength of th } \\
\text { mover }\end{array}$ & & 0,05 & 0,10 & & 0,15 & 0,20 & 0,1 & ,10 & ,10 & & 0,10 & 0,10 \\
\hline Religion & 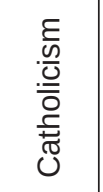 & 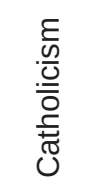 & 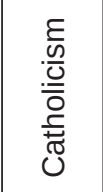 & 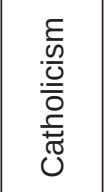 & 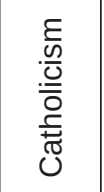 & 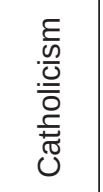 & $\begin{array}{l}\widehat{\widehat{x}} \\
\frac{0}{0} \\
\text { D } \\
\text { ț } \\
0\end{array}$ & 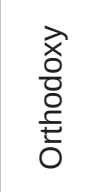 & 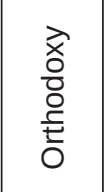 & 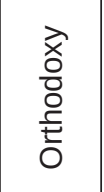 & 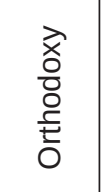 & $\begin{array}{l}\overrightarrow{\widehat{x}} \\
\text { o } \\
\text { o } \\
\text { 0े }\end{array}$ \\
\hline Ratification of U.N. convention & 1 & 5 & 9 & 14 & 18 & 22 & 13 & 17 & 21 & 13 & 17 & 21 \\
\hline Abortion rights & 1 & 1 & 1 & 0 & 0 & 0 & 1 & 1 & 1 & 1 & 1 & 1 \\
\hline Electoral system & 2 & 2 & 2 & 2 & 2 & 2 & 1 & 1 & 1 & 0 & 1 & 2 \\
\hline Left party government & 0,2 & 0,24 & 0,24 & 0,46 & 0,35 & 0,46 & 0,66 & 0,25 & 0,24 & 0,26 & 0,43 & 0,25 \\
\hline Degree of democracy & 2,5 & 2 & 1,5 & 2 & 1,5 & 1,5 & 3,5 & 4 & 5 & 3,5 & 3,5 & 4 \\
\hline
\end{tabular}

Source: created by the author 
Table of significant variables of women's parliamentarism

able 2

\begin{tabular}{|c|c|c|c|c|c|c|c|}
\hline & 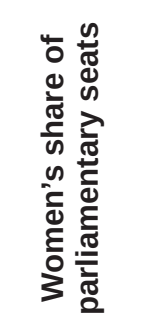 & 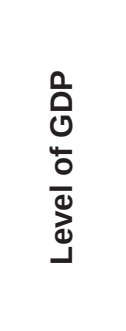 & $\frac{\overline{0}}{\frac{\sigma}{\sigma}}$ & 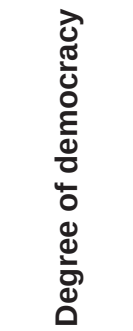 & 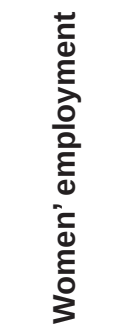 & 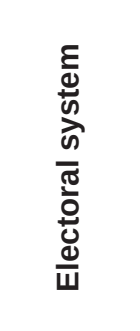 & 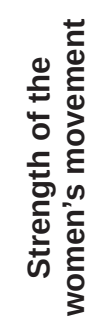 \\
\hline $\begin{array}{c}\text { Women's share } \\
\text { of parliamentary seats }\end{array}$ & 1 &, $776(* *)$ &,$- 754(* *)$ &,$- 718\left(^{* \star}\right)$ &,$- 667(* \star)$ & ,608(*) &, $580\left(^{*}\right)$ \\
\hline Level of GDP &, $776(* *)$ & 1 &,$- 639\left(^{*}\right)$ &,$- 587\left(^{*}\right)$ &,$- 591\left(^{*}\right)$ &, $534(*)$ & 0,34 \\
\hline Religion &,$- 754\left({ }^{\star \star}\right)$ &,$- 639\left(^{*}\right)$ & 1 & 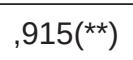 & ,910(**) &,$- 775\left({ }^{\star \star}\right)$ & $-0,241$ \\
\hline Degree of democracy &, $718\left(^{* \star}\right)$ &,$- 587(*)$ & $915(\star \star)$ & 1 & ,832(**) &,$- 652\left(^{*}\right)$ & $-0,305$ \\
\hline Women's employment &,$- 667(* \star)$ &,$- 591\left(^{*}\right)$ & ,910(**) & ,832(**) & 1 &,$- 705(* \star)$ & $-0,2$ \\
\hline Electoral system & ,608(*) & ,534(*) &,$- 775\left(^{(* *}\right)$ &,$- 652\left(^{*}\right)$ &,$- 705\left(^{(\star \star}\right)$ & 1 & 0,216 \\
\hline
\end{tabular}

Note: ${ }^{* \star}$ Correlation is significant at the level of $0.01 ;{ }^{*}$ Correlation is significant at the level of 0.05 . Source: created by the author

Pearson's correlation $r=\sum_{i=1}^{N}\left(X_{i}-X\right)\left(Y_{i}-\bar{Y}\right)(N-1) S_{x} S_{y}$

Table 3

\begin{tabular}{|c|c|c|c|c|c|c|c|c|c|c|c|c|c|}
\hline & 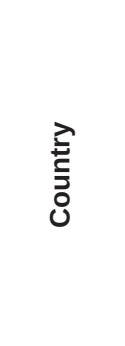 & ঠむ & 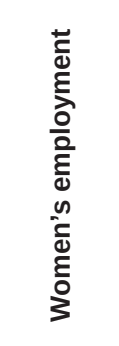 & 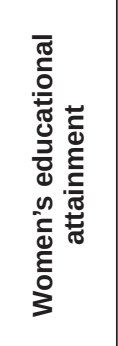 & 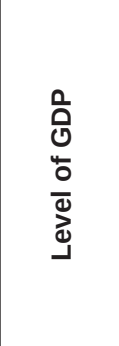 & 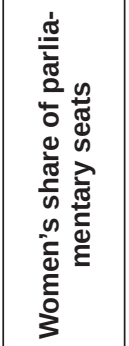 & 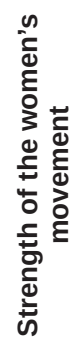 & $\frac{\overline{0}}{\frac{0}{\overline{0}}}$ & 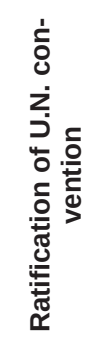 & 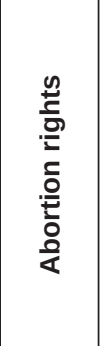 & 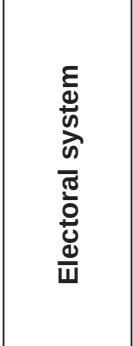 & 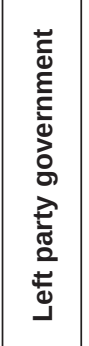 & 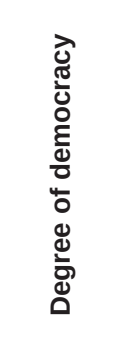 \\
\hline County & 1 & ,000 &, $881\left({ }^{\star \star}\right)$ & ,451 & $680(* *)$ &,$- 78{ }^{(* *)}$ &,- 346 & ,894(**) & ,624(*) & 258 & $693\left({ }^{(*)}\right)$ & ,185 & ,736(** \\
\hline Year & - & 1 & 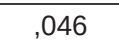 & ,427 & $993\left(^{*}\right)$ & , 126 &,- 203 & 000 &, $521(*)$ & ,000 & ,316 &,- 300 & ,045 \\
\hline $\begin{array}{r}\text { Womer } \\
\text { employm }\end{array}$ & $81(* *)$ & ,046 & 1 & 397 &,$- 591\left(^{*}\right)$ &,$- 667\left({ }^{*}\right)$ &,- 621 &, $\left.910{ }^{(* *}\right)$ & 423 & $\mid, 525\left(^{*}\right)$ &,$\left.- 705^{(\star \star}\right)$ & 086 &, $832(* \star)$ \\
\hline \begin{tabular}{|c|} 
Women's \\
educational \\
attainment \\
\end{tabular} & 451 & ,427 & , 3 & 1 & 139 & - 200 & -168 & 493 &, $\left.688{ }^{(* *}\right)$ & \begin{tabular}{|l|l|}
,- 035 \\
\end{tabular} &,$- 603(*)$ & , 146 & 493 \\
\hline Level of GDP & $00^{*}$ & $3\left({ }^{*}\right)$ & $91\left(^{*}\right)$ & 13 & 1 &, $776\left({ }^{* *}\right)$ & ,093 &,- 639 & 023 & 312 & $534\left(^{*}\right)$ & -106 &,- 587( \\
\hline \begin{tabular}{|c|} 
Women's \\
share of \\
parliamenary \\
seats
\end{tabular} &,$- 780(* \star)$ & 126 &,$- 667(* *)$ & - -200 &, $776\left(^{* \star}\right)$ & 1 & 149 &,$- 754\left(^{(*)} \mid\right.$ &,- 235 & $\mid-, 470$ & ,608(*) & ,328 &,$\left.- 718{ }^{(\star *}\right)$ \\
\hline $\begin{array}{c}\text { Strengh } \\
\text { of the } \\
\text { women's } \\
\text { movement }\end{array}$ & - 346 & $\mid-, 203$ & 21 & -168 & 093 & 149 & 1 &,- 539 &,- 036 & \begin{tabular}{|l|}
-657 \\
\end{tabular} & ,431 & $\mid-, 049$ &,- 513 \\
\hline Religic & +1 & & ,910(**) & , & $339\left(^{*}\right)$ &,$-- 754\left({ }^{(\star)}\right)$ & 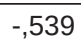 & & ,438 & $\left.\mid, 5777^{*}\right)$ & $\begin{array}{l}-, 775(\star \star) \\
\end{array}$ & \begin{tabular}{|l|}
, 088 \\
\end{tabular} & ,915(**) \\
\hline $\begin{array}{c}\text { Ratification of } \\
\text { U.N. conven- } \\
\text { tion }\end{array}$ &, $624\left(^{*}\right)$ &, $521\left(^{*}\right)$ & 423 & ,688(**) &,- 023 &,- 235 &,- 036 & 438 & 1 & \begin{tabular}{|l|}
-345 \\
\end{tabular} & -175 & ,266 & ,348 \\
\hline $\begin{array}{c}\text { Abortion } \\
\text { rights }\end{array}$ & ,258 & ,000 &, $525\left(^{*}\right)$ &,- 035 &,- 312 &,- 470 &,- 657 &, $577\left(^{*}\right)$ &,- 345 & 1 & -,447 &,- 377 &, $613\left({ }^{\star}\right)$ \\
\hline $\begin{array}{l}\text { Electoral } \\
\text { system }\end{array}$ &,$- 693(* \star)$ & ,316 &,$\left.- 7055^{(\star *}\right)$ &,$- 603\left(^{\star}\right)$ &, $534\left(^{*}\right)$ &, $608\left(^{\star}\right)$ & ,431 &,$- 775\left(^{(\star)}\right.$ &,- 175 &,- 447 & 1 &,- 078 &,$- 652\left(^{*}\right)$ \\
\hline \begin{tabular}{|c|} 
Left party \\
government
\end{tabular} & 185 & $\mid-, 300$ & , & 146 & -,106 & ,328 &,- 049 & 8 & ,266 & \begin{tabular}{|l|}
-377 \\
\end{tabular} &,- 078 & 1 & -,119 \\
\hline $\begin{array}{l}\text { Degree of } \\
\text { democracy }\end{array}$ &, $\left.736{ }^{(\star \star}\right)$ & ,045 &, $832(* \star)$ & 493 &,$- 587\left(^{*}\right)$ &, $718\left(^{* *}\right)$ &,- 513 &, $915{ }^{(* *)}$ & ,348 &, $613\left(^{*}\right)$ &,$- 652\left(^{*}\right)$ &,- 119 & 1 \\
\hline
\end{tabular}

Note: ${ }^{*}$ Correlation is significant at the level of 0.01; ${ }^{*}$ Correlation is significant at 0.05 . Source: created by the author 
be most closely associated with the indicator of women parliamentarism, which, however, is not confirmed in most researches. The exception is the work by $\mathrm{J}$. Viterna, J. Beckfield, and K. Fallon (2008) [36], where the statistical model clearly demonstrates that this variable positively correlates with the level of women's parliamentarism.

While the socio-economic variables has justified to some extent the expectations regarding the degree of interconnection, the effectiveness of cultural variables almost did not confirm its relevance. Such variables as "ratification of CEDAW" and "abortion rights" did not appear statistically significant in research. The variable as the "type of dominant religion" demonstrated the maximally negative connection $(-0,754)$ with the dependent variable. Having justifyed the initial theoretical premise that those religions (Catholicism and Orthodoxy), defending traditional roles for women, tend to prevent the women's political activity. This is confirmed by the number of studies revealing that the parliaments of the countries of the Northern and Sub-Saharan Africa, Asia and the Pacific, Latin America and Eastern Europe have less proportion of women than the countries of Western Europe, where Protestantism predominates.

In accordance with the analysis of the data presented in the general matrix of significant variables of women's parliamentarism (Table 2), it is obvious that the number of political indicators play a central role in determining the degree of gender inequality in political representation. We find significant support for the political empowerment of women by such variables as "electoral system" and the "degree of democracy". The correlation coefficient of the variable "left party government", although demonstrating the expected positive connection, is far from being statistically significant.

Our results have confirmed the relevance of some political determinants, which is consistent with most similar researches. Many previous works, studying the practice of stable democratic states, have found that the structure of the electoral system is the most important parameter of women's success in achieving political representation. The findings have confirmed this discovery and spread these conclusions to the countries demonstrating new wave of democracy.

Thus, the presented research model is able to explain almost two thirds of the facts with the maximum probability of fluctuations in the level of women political representation. This is a fairly high index of reliability (in the regression with 13 variables and only 12 cases), however, the model leaves virtually one third of the variations without explanations. What reasons do make it difficult to verify all model's data? A number of independent variables that are used in the analysis suffer from the error of measurement. Moreover, even those variables, the data for which are available in a number of countries, have doubtful reliability. This concerns such an indicator as the "strength of the women's movement", which shows one of the highest levels of standard deviation (4,649).
As the model shows, the number of women's political organizations does not directly influence the political women participation. However, despite the fact that this variable is not valid, it is doubtful to deny its influence on women's political representation, since both the initial theoretical construction and a number of researches have supposed that a vibrant women's movement can play a critical role in expanded women's parliamentarism.

Some of the variables, namely, the "share of women employed in skilled labor," had to be excluded from the analysis due to the lack of reliable data (however, the value of this variable is significant at L. Kenworthy and M. Malami (1999) [17]. In our case the lack of positive correlation from such variables as "employment" and "educational level" may have resulted from the fact that our statistical model did not include in the list such variable as "share of women employed in skilled labor".

Thus, the discovery of significant effects of some variables and the absence of the influence of others could occur due to the absence (or presence) explaining's variables in the model. To a certain extent, our research suffers from the error of measurement of variables and their more complete set. Taking these priori limitations into account, we consider our analysis as relatively successful.

It is necessary to take into account, as L. Kenworthy and M. Malami (1999) specify, when the analysis is limited to rich stable democracies, for which the data are more complete and more reliable, selected variables can embrace to $90 \%$ of reliable variations in explaining women's political representation.

The results obtained have indicated that political, socio-economic and cultural factors play different role in terms of influencing the political women representation. Some variables are characterized as having a positive intercommunication with the indicator of female parliamentarism. Others, on the contrary, do not show a similar correlation. In this regard, women's political representation is similar to many important social phenomena. However, it can be assumed that socioeconomic and cultural factors are less significant than theoretical expectations about their impact on gender equality in the political sphere.

Despite the strong view that reducing gender inequalities in the socio-economic sphere is a critical condition in terms of the empowerment of women in politics, our study showed that the level of women education is not related to the indicator of female parliamentarism, and the measure of bringing them to paid employment demonstrated feedback with a dependent variable.

The only socio-economic indicator that had a direct impact on the dependent variable was the level of the country's GDP. However, despite the fact that the correlation coefficient of this variable is the highest, it also showed a small degree of deviation (2.22). Thus, we suppose that the change in the functioning of political institutions may be more effective, but not less easy way for the expansion of political opportunities for women. 
The data presented in the statistical model to a certain measure coincide with the similar data in the framework of international analysis, and in some cases contradict general conclusions. Two of the three political variables behave as expected. The degree of democracy and the presence of the proportional electoral system contribute to the expansion of political opportunities for women, while the percentage of left-wing parties has not demonstrated a significant interconnection.

The results of the influence of socio-economic factors were slightly weaker. The habitual expectations about the relevance of the part of cultural determinants have not been confirmed in our analysis as well. Such an outcome undermines confidence in the appropriateness of considering the validation of CEDAW and the legalization of abortion as significant variables.

The level of GDP turned out to be the only socio-economic indicator related to women political representation. Catholicism and Orthodoxy, as expected, do not contribute to women's success in winning the elections, showing a correlation with the negative value. Thus, such variables as "women's educational attainment", "strength of the women's movement", "ratification of CEDAW", "abortion rights" and "left party government" were not related to gender inequality in the political sphere. Such variables as the "level of GDP", "electoral system", "religion" and the "degree of democracy" demonstrated the type of connection that was expected from theoretical constructions.

Considering the results obtained - significant influence of such factors as "electoral system", "level of GDP", "religion" and "degree of democracy", on women's political participation, we consider that these variables deserve to be included into the study of gender inequality in political representation. At the same time, we agree with the opinion of those researchers - J. Viterna, J. Beckfield, K. Fallon (2008) [36], R. Matland (2003) [21], that all existing models are not able to fully identify the factors, encouraging women's political representation beyond the experience of stable democratic states.

Although our research mainly discusses with conclusions of L. Kenworthy and M. Malami (1999), taking into account the consistent usage of these variables in the works of many researchers of female parliamentarism, we assume that these authors would come to similar results if they studied the experience of stable democratic states and the states of new wave states democracy apart.

However, the results of our model (the importance of political factors, the lack of influence from a number of socio-economic indicators), in general, act in accordance with the theoretical expectations of the constructed model by L. Kenworthy and M. Malami (1999) for Western Europe [17]. However, the existing measurement error requires further verification of the main indicators, as well as the advancement of new hypotheses regarding the processes in which women are politically empowered in CEE countries.
Conclusions. The results of statistical verification of hypotheses presented in the model, in general, coincide with the similar ones within the framework of international analysis, and in some cases contradict the findings of the Western studies on gender inequality in politics. Thus, the degree of democracy and the presence of a proportional electoral system were found to contribute to the expansion of political opportunities for women, but the percentage of left-wing parties in parliament did not show a significant connection. Despite the expectations, the women's educational attainment and the strength of the women's movement were not statistically significant in the model. The habitual expectations about the relevance of a part of cultural determinants have not been confirmed in our analysis as well. The level of economic development is the only socio-economic variable that is associated with women's political representation. Catholicism and Orthodoxy, as expected, do not contribute to women's success in winning elections, demonstrating a correlation dependence with a negative value.

Such variables as "women's educational attainment", "strength of women's movement", "ratification of CEDAW", "abortion rights" and "left party government" turned out to be unrelated to the indicator of women's parliamentarism in CEE countries. Such variables as "level of GDP", "electoral system", "religion" and the "degree of democracy" demonstrated the type of communication that was provided by the theoretical model. Taking these results into account, we consider that the variables mentioned above deserve to be included into the development of the conceptual framework of the analysis of the women representation in the authority bodies of the countries with the transitional economies.

\section{REFERENCES:}

1. Aliancia zien Slovenska. Historia a Výročné správy. Retrieved June 10, 2019. URL : http://www.alianciazien.sk/index.php?page=20.

2. Baza Fundacja Kobieca «eFKa». URL http://efka.org.pl/en/home/.

3. Baza Organizacji Aliancia zien. URL http://www.alianciazien.sk/index. php?page=pub.

4. Central Election Commission of Russian Federation. URL : https://www.cikrf.ru.

5. Central Election Commission of Ukraine. URL : https://www.cvk.gov.ua/.

6. Eurasian Women's Community. URL : http://eawfpress.ru/en/.

7. Federal State Statistics Service of the Russian Federation. URL : http://www.gks.ru/wps/wcm/connect/ rosstat_main/rosstat/en/main/.

8. Freedom House. URL : https://freedomhouse.org.

9. Fundacja Centrum Promocji Kobiet. URL : .

10. Fundacją Równość.info. URL : https://rownosc. info/org_bank/list.

11. Government Office of the Slovak Republic. URL : https://www.vlada.gov.sk// government-of-the-slovakrepublic/.

12. Government Portal of Ukraine. URL https://www.kmu.gov.ua/en. 
13. Inter-Parliamentary Union. URL : https://www.ipu.org.

14. Inglehart, R., Norris, P., Welzel, C. (2002). Gender equality and Democracy. Comparative Sociology. 1(3-4). P. 235-264.

15. Jones, Mark P. (2007). Democracy in Latin America. Challenges and Solution: Political Party and Party System Institutionalization and women's Legislative Representation. Retrieved May 25, 2019. URL : http:// www.copenhagenconsensus.com/sites/default/files/ democracy_jones_sp_3v.pdf.

16. Kancelaria Prezesa Rady Ministrow Rzeczpospolita Polska. URL : http://www.kprm.gov.pl/s.php?id=474.

17. Kenworthy, L., Malami, M. (1999). Gender Inequality in Political Representation: A Worldwide Comparative Analysis. Social Forces, 78(1), 235-269.

18. Lindberg, S.I. (2004). Women' Empowerment and Democratization: The Effects of Electoral Systems, Participation, and Experience in Africa. Studies in Comparative International Development, 39(1), 28-53.

19. Matland, R. (2005). Explaining Women's Representation: The Role of Legislative Recruitment \& Electoral Systems. Retrieved May 27, 2019. URL : http:// www.iknowpolitics.org/sites/default/files/ep.4_matland. pdf

20. Matland, R., Ballington, G. (2004). Political Parties and Special Measure: Enhancing Women's Participation in Electoral Processes. Retrieved June 1, 2019. URL : http:// archive.idea.int/newsletters/2004/ electoral_quotas.pdf.

21. Matland, R.M. (2003). Recruiting Women to National Legislatures: A General Framework with Application to Post-Communist Democracies. In: R.M. Matland and R.M. Montgomery (eds.). Women's Access to Political Power in Post-Communist Europe. New York : Oxford University Press Inc., 19-42.

22. Ministry of Justice of the Russian Federation. URL : https://minjust.ru/.

23. Ministry of Justice of Ukraine. URL : https://minjust. gov.ua/en.
24. Ministry of the Interior of the Slovak Republic. URL : https://www.minv.sk/?ministry-of-interior.

25. National Court Register in Poland. URL : https:// www.gov.pl/web/sprawiedliwosc/krajowy-rejestr-sadowy.

26. Norris, P., Inglehart, R. (2000). Cultural barriers to women's leadership: A worldwide comparison. Retrieved June 3, 2019. URL : http://www.onlinewomeninpolitics.org/ beiijing 12/ipsa2000 culture.pdf.

27. Panstwowa komisja wyborcza. URL : https://pkw.gov.pl/.

28. State Statistics Service of Ukraine. URL : http:// ukrstat.org/en/work/contakt_e.html.

29. Statistical office of the Slovak Republic. URL https://slovak.statistics.sk.

30. Statistical office of the Slovak Republic. Elections and referenda. URL : https://web.archive.org/ web/20190331044517/http://volby.statistics.sk/index-en. html.

31. Statistics Poland. URL : https://stat.gov.pl/en/.

32. Szymanczak J. (1994). Wykaz organizacji i ruchów kobiecych w polsce. Retrieved June 15, 2019. URL : http:// biurose.sejm.gov.pl/teksty_pdf_94/i-210.pdf.

33. The Russian Government. URL : http://government. ru/en/.

34. Ukrainian women's fund. URL : https://www.uwf. org.ua/about/us.

35. Ukrainian women's portal. URL : http://portal.uwf. org.ua/index.php?page=base1.

36. Viterna, J., Fallon K. M., Beckfield, J. (2008). Development, democracy, and women's legislative representation: Re-visiting existing explanations of gender variation in the world's parliaments. International Journal of Comparative Sociology, 49(6), 457-477. Retrieved May 21, 2019. URL : https://www.researchgate.net/ publication/241535103_Development_Democracy_and Women\%27s_Legislative_Representation_ReVisiting_ Existing Explanations_of_Gender_Variation_in_the World\%27s_Parliaments.

\section{Політична участь жінок країн Центральної і Східної Європи: порівняльний аналіз}

Сурніна-Далекорей

Ольга Анатоліївна

кандидат політичних наук, доцент кафедри політології і державного управління Ужгородського національного університету

вул. Університетська, 14,

Ужгород, Україна
У статті досліджується процес трансорормації політичної участі жінок під впливом різних фракторів у формі порівняльного аналізу. Метою дослідження є виявлення та систематизачія фракторів, що впливають на рівень політичної участі жінок у країнах із перехідною економікою. Актуальність теми визначається необхідністю включення жінок як активних учасників у політичний процес країн, що розвиваються, та створення механізмів, що сприяють зростанню ролі жінок в органах влади як чинної умови представницької демократії. Методологія дослідження базується на теоретичних підходах до аналізу політичного представничтва та участі жінок в органах влади, а також на основі концепції, згідно з якою стан політичної участі жінок визначається комплексом соціально-економічних, культурних та політичних факторів. Загальна література, що стосується жінок і політики, включає три основні кластери змінних до пояснення національних варіацій у рівні представництва жінок у владі: соціально-економічні (рівень зайнятості жінок, рівень освіти жінок, економічний розвиток держави, сила жіночого руху), політичні (виборча система, наявність лівих партій, рівень демократії) та культурні (домінуюча релігія, ратифікація конвенції ООН про ліквідацію дискримінації щодо жінок, легалізація абортів). Емпіричну основу роботи складає широке коло статистичних даних. Працюючи з ними, авторка використовувала елементи статистичного аналізу та комп'ютерні методи оброблення даних (у стандартному пакеті SPSS). Cтатистичний аналіз тенденцій політичної участі жінок у Словаччині, Польщі, Україні та Росії продемонстрував, що рівень соціальноекономічного розвитку, відповідне культурне середовище та інституційні чинники $\epsilon$ важливими механізмами, що визначають рівень політичної участі жінок у перехідних країнах.

Ключові слова: Центральна і Східна Європа, Словаччина, Польща, Росія, Україна, політична участь жінок. 